\title{
Extreme overirradiance events in São Paulo, Brazil
}

\author{
Marcelo Pinho Almeida , Roberto Zilles , Eduardo Lorenzo
}

\begin{abstract}
Phenomena of overirradiance have been pointed all over the World. This note presents the most extreme enhancement event reported in Brazil, which contains an irradiance reading of $1590 \mathrm{~W} / \mathrm{m}^{2}$ measured in São Paulo (latitude $23^{\circ} 32^{\prime} \mathrm{S}$ ) at relatively low altitude ( $760 \mathrm{~m}$ a.s.1.).
\end{abstract}

Keywords: Overirradiance; Cloud enhancement; São Paulo; Brazil

\section{Introduction}

Overirradiance caused by cloud enhancement has been plenty discussed by many authors throughout the years (Antón et al., 2011; Emck and Ritcher, 2008; Gu et al., 2001; Hansen et al., 2010; Luoma et al., 2012; Piacentini et al., 2003, 2011; Piedehierro et al., 2014; Suehrcke and McCormick, 1988; Tapakis and Charalambides, 2014; Weigl et al., 2012; Yordanov et al, 2013a,b), and the phenomenon is expected to be more intense at tropical latitudes in the Southern Hemisphere, at high plateaus and mountains (Yordanov et al., 2013b). Cloud enhancement has been traditionally related to reflection of sun radiation on the borders of Cumulus clouds around the sun disc, with the sun unobstructed. Recently, another explanation has been proposed: strong forward Mie scattering of sun light inside the clouds within a narrow angle around the solar disc (Yordanov et al., 2013a). A discussion about the real foundation of cloud enhancement is beyond the scope of this note.

A record maximum irradiance of $1832 \mathrm{~W} / \mathrm{m}^{2}$ (Emck and Ritcher, 2008) was registered in the Andes (Ecuador) at $3400 \mathrm{~m}$ a.s.1., however other several interesting events are reported in the literature (see Table 1) with a substantial difference regarding the resolution of measurements (from $10 \mathrm{~ms}$ up to $300 \mathrm{~s}$ ) and the response time of the instruments (from $10 \mu$ s up to $18 \mathrm{~s}$ ).

The measurements used in this note were taken at São Paulo University, at $760 \mathrm{~m}$ a.s.1., and revealed the highest irradiance value reported for Brazil and for altitudes below $1000 \mathrm{~m}$ a.s.l. worldwide. This note is intended to present a short analysis of two selected days from November and December, which presented the two highest irradiance readings from the period analyzed. Both these days were characterized by partially clouded sky, and Fig. 1 shows a series of photographs of the sky conditions.

\section{Measurement setup}

Irradiance and open circuit voltage (Voc) are being recorded at 1-s time intervals with an Agilent 34970A Data 
Table 1

Maximum irradiance registered during cloud enhancement events around the World.

\begin{tabular}{|c|c|c|c|c|c|c|c|c|}
\hline References & $\begin{array}{l}\text { Maximum } \\
\text { irradiance } \\
\left(\mathrm{W} / \mathrm{m}^{2}\right)\end{array}$ & $\begin{array}{l}\text { Altitude } \\
(\mathrm{m})\end{array}$ & Location & $\begin{array}{l}\text { Plan of } \\
\text { measurement }\end{array}$ & $\begin{array}{l}\text { Duration of } \\
\text { measurement }\end{array}$ & $\begin{array}{l}\text { Instrument of } \\
\text { measurement }\end{array}$ & $\begin{array}{l}\text { Resolution of } \\
\text { measurements } \\
\text { (s) }\end{array}$ & $\begin{array}{l}\text { Response time of } \\
\text { instrument, } 95 \% \text { of final } \\
\text { value (s) }\end{array}$ \\
\hline $\begin{array}{l}\text { Emck and Ritcher } \\
\text { (2008) }\end{array}$ & 1832 & 3400 & $\begin{array}{l}\text { Ecuador } \\
\text { (Andes) }\end{array}$ & Horizontal & 4 years & $\begin{array}{l}\text { Pyranometer } \\
\text { (CM3) }\end{array}$ & 300 & $\leqslant 18$ \\
\hline $\begin{array}{l}\text { Yordanov et al. } \\
\text { (2013a) }\end{array}$ & $>1800$ & 1131 & Kenya (Kisumu) & - & - & - & - & - \\
\hline Present paper & 1590 & 760 & $\begin{array}{l}\text { Brazil (Săo } \\
\text { Paulo) }\end{array}$ & Horizontal & $<1$ year & $\begin{array}{l}\text { PV module } \\
\text { (MSX-10) }\end{array}$ & 1 & $\leqslant 10^{-5}$ \\
\hline $\begin{array}{l}\text { Tapakis and } \\
\text { Charalambides } \\
\text { (2014) }\end{array}$ & 1533 & 360 & Cyprus & Horizontal & 1 year & $\begin{array}{l}\text { Pyranometer } \\
\text { (MS-802) }\end{array}$ & $<60$ & $\leqslant 5$ \\
\hline $\begin{array}{l}\text { Piacentini et al. } \\
\text { (2003) }\end{array}$ & 1528 & 3900 & $\begin{array}{l}\text { Argentina (Puna } \\
\text { of Atacama) }\end{array}$ & Horizontal & $<1$ year & $\begin{array}{l}\text { Pyranometer } \\
\text { (PSP Eppley) }\end{array}$ & 5 & $\leqslant 15$ \\
\hline $\begin{array}{l}\text { Yordanov et al. } \\
\text { (2013a) }\end{array}$ & 1528 & 60 & $\begin{array}{l}\text { Norway } \\
\text { (Grimstad) }\end{array}$ & Tilted $\left(39^{\circ}\right)$ & $<1$ year & $\begin{array}{l}\text { mc-Si PV Cell } \\
\text { (Soldata } 80 \mathrm{spc} \text { ) }\end{array}$ & $10^{-2}$ & $\leqslant 0.025^{*}$ \\
\hline Weigl et al. (2012) & $>1500$ & $<10$ & USA (Oahu) & Horizontal & - & $\begin{array}{l}\text { Pyranometer } \\
\text { (LICOR LI-200) }\end{array}$ & 1 & $\leqslant 10^{-5}$ \\
\hline $\begin{array}{l}\text { Piacentini et al. } \\
\text { (2011) }\end{array}$ & 1477 & 4 & Brazil (Recife) & Horizontal & 1 year & $\begin{array}{l}\text { Pyranometer } \\
\text { (PSP Eppley) }\end{array}$ & $\leqslant 60$ & $\leqslant 15$ \\
\hline $\begin{array}{l}\text { Hansen et al. } \\
\text { (2010) }\end{array}$ & $>1400$ & 1620 & $\begin{array}{l}\text { USA } \\
\text { (Albuquerque) }\end{array}$ & Horizontal & $<1$ year & $\begin{array}{l}\text { Pyranometer } \\
(\mathrm{CM}-21)\end{array}$ & 60 (average) & $\leqslant 5$ \\
\hline Gu et al. (2001) & $>1400$ & $<400$ & $\begin{array}{l}\text { Brazil } \\
\text { (Rondônia) }\end{array}$ & Horizontal & $<1$ year & $\begin{array}{l}\text { Pyranometer } \\
\text { (PSP Eppley) }\end{array}$ & 60 (average) & $\leqslant 15$ \\
\hline Luoma et al. (2012) & $>1300$ & 22 & $\begin{array}{l}\text { USA (San } \\
\text { Diego) }\end{array}$ & Horizontal & - & $\begin{array}{l}\text { Pyranometer } \\
\text { (LICOR LI-200) }\end{array}$ & 1 & $\leqslant 10^{-5}$ \\
\hline $\begin{array}{l}\text { Piedehierro et al. } \\
\text { (2014) }\end{array}$ & 1244 & 680 & Spain (Granada) & Horizontal & 5 years & $\begin{array}{l}\text { Pyranometer } \\
(\mathrm{CM}-11)\end{array}$ & 60 & $\leqslant 15$ \\
\hline
\end{tabular}

"The response time of Soldata 80 spc is specified up to $90 \%$ of final value.

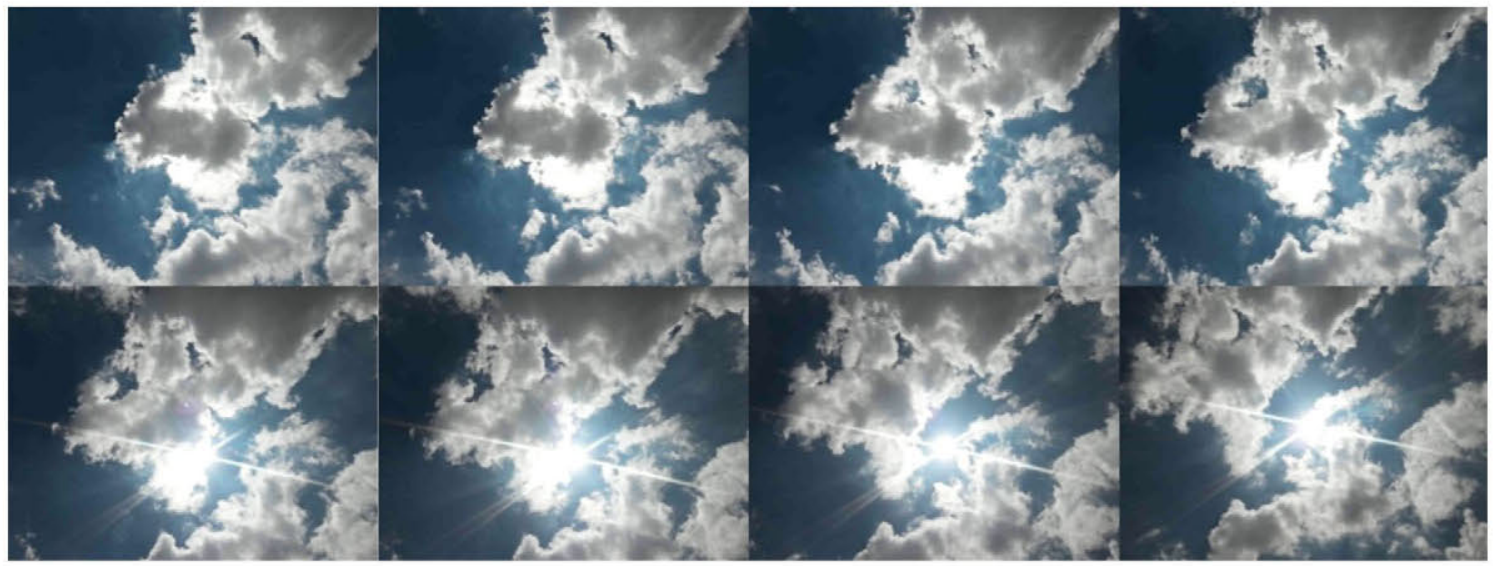

Fig. 1. Examples of sky conditions around 13:00 on November 27th, but they do not necessarily represent the moments of maximum irradiance.

Logger. The irradiance sensor is a polycrystalline MSX-10 PV module with a $0.1 \Omega$ shunt resistor, calibrated against two different monocrystalline reference PV cells under real sun conditions (the cells were calibrated against a secondary standard module from CIEMAT and the difference between their readings is smaller than $\pm 1 \%$ ). The accuracy of final irradiance measurement is estimated to be better than $\pm 5 \%$ for values above $700 \mathrm{~W} / \mathrm{m}^{2}$.

It is known that overirradiance events caused by cloud enhancement are extremely dynamic, and, due to their own nature, short-lived. Therefore, high-resolution measurement (small sampling time) is necessary to effectively 


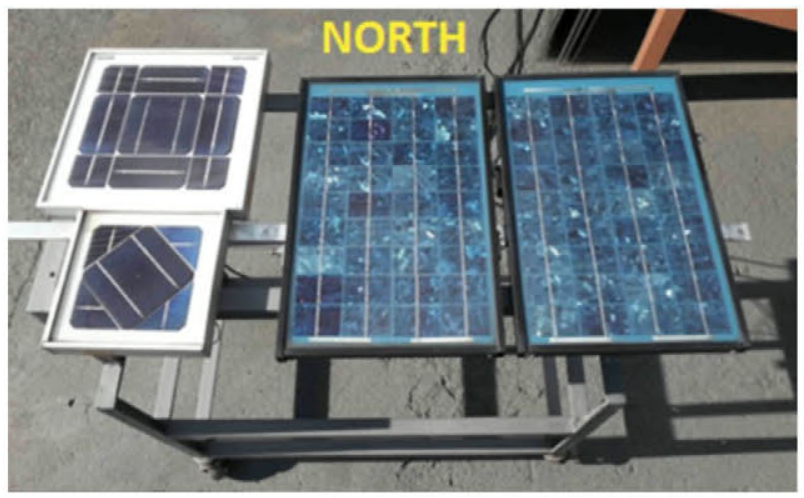

Fig. 2. Polycrystalline MSX-10 PV modules used to measure irradiance (center) and open circuit voltage (right). The two reference cells used for calibration are on the left.

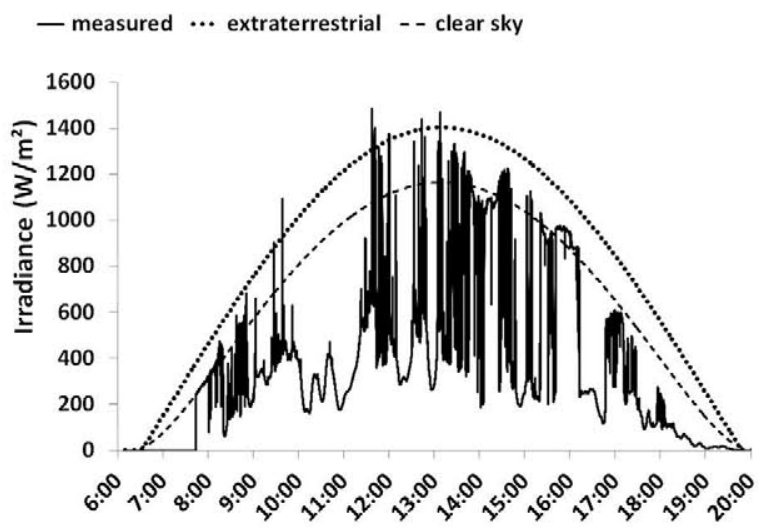

Fig. 3. Global horizontal irradiance on November 27th.

study this phenomenon and to obtain statistically significant data. Following the procedure suggested by Yordanov et al. (2013a), the maximum error due to the 1-s sampling time is $17 \mathrm{~W} / \mathrm{m}^{2}$, resulting in an expanded uncertainty of about $5.1 \%$ for the peak of $1590 \mathrm{~W} / \mathrm{m}^{2}$ registered on December 21st.

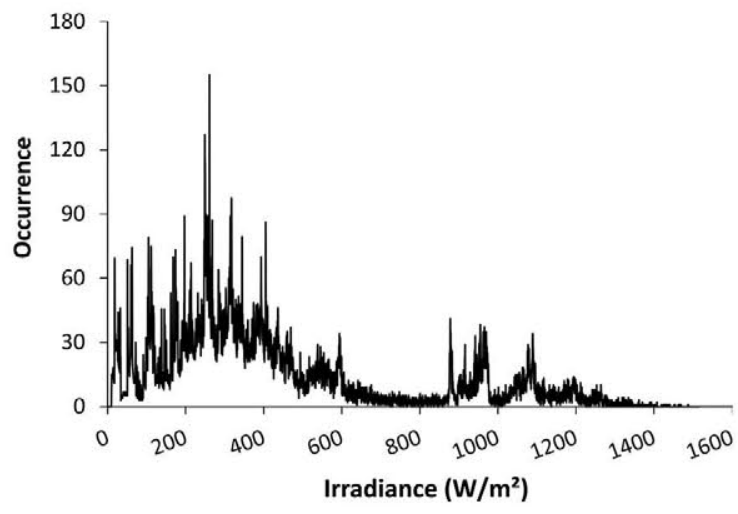

(a)
The open circuit voltage of another MSX-10 module (with $\mathrm{Voc}_{\mathrm{STC}}=20.8 \mathrm{~V}$ ) is also being registered, so some short paragraphs will be addressed to the open circuit voltage of photovoltaic devices under overirradiance condition. Nevertheless, it is worth to state that a definite conclusion about overirradiance effects over photovoltaic systems is beyond the scope of this note, and the voltage measurements were added as a complement to show that VOC $_{\text {STC }}$ was not exceeded during the extreme overirradiance events.

Fig. 2 presents the mounting rack with the reference cells and the MSX-10 modules during calibration period.

\section{Results for November 27th}

The highest reading on November 27th was $1487 \mathrm{~W} / \mathrm{m}^{2}$, while the estimated clear-sky irradiance for the same moment is $1100 \mathrm{~W} / \mathrm{m}^{2}$, which leads to an enhancement factor of 1352. The clear-sky irradiance was computed using the European Solar Radiation Atlas model (Rigollier et al., 2000), considering a constant Linke Turbidity factor for the entire day and using measured clear-sky irradiance to tune the model. Fig. 3 shows the measured global horizontal irradiance and the theoretical clear sky and extraterrestrial ones.

Fig. 4 shows the frequency distribution of irradiance, and from Fig. $4 \mathrm{~b}$ one can easily identify a considerable amount of readings above $1000 \mathrm{~W} / \mathrm{m}^{2}(10 \%$ of all readings).

Fig. 5 gives details on the amount of irradiation in a specific range of irradiance and the percentage of time the readings remained in this range. From the daily measured irradiation of $4.99 \mathrm{~kW} \mathrm{~h} / \mathrm{m}^{2}, 24.4 \%$ correspond to irradiances above $1000 \mathrm{~W} / \mathrm{m}^{2}$.

The readings higher than the extraterrestrial irradiance can be grouped into 15 continuous events, whose durations and quantities are presented in Table 2.

The short circuit current of a PV generator can be directly related to the irradiance readings, being the

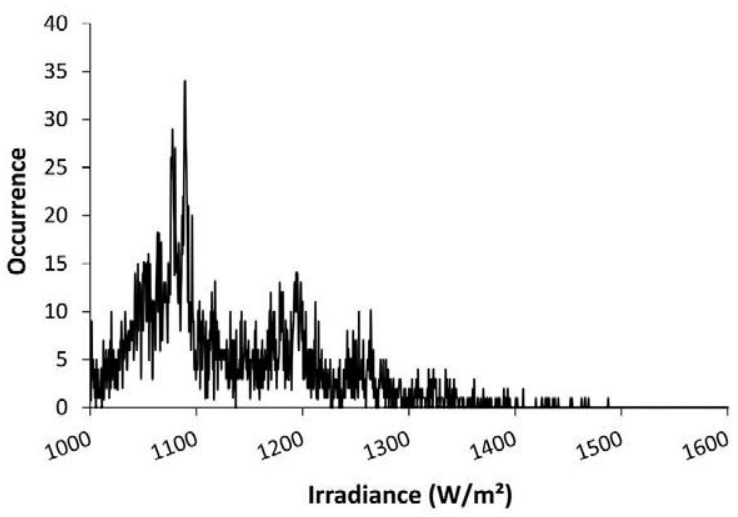

(b)

Fig. 4. Frequency distribution of irradiance (a) from 0 to $1600 \mathrm{~W} / \mathrm{m}^{2}$ and (b) detail from 1000 up to $1600 \mathrm{~W} / \mathrm{m}^{2}$. 


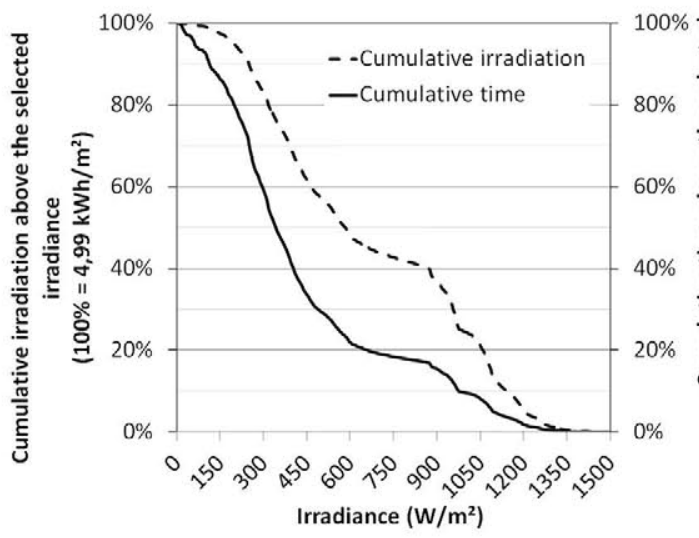

(a)

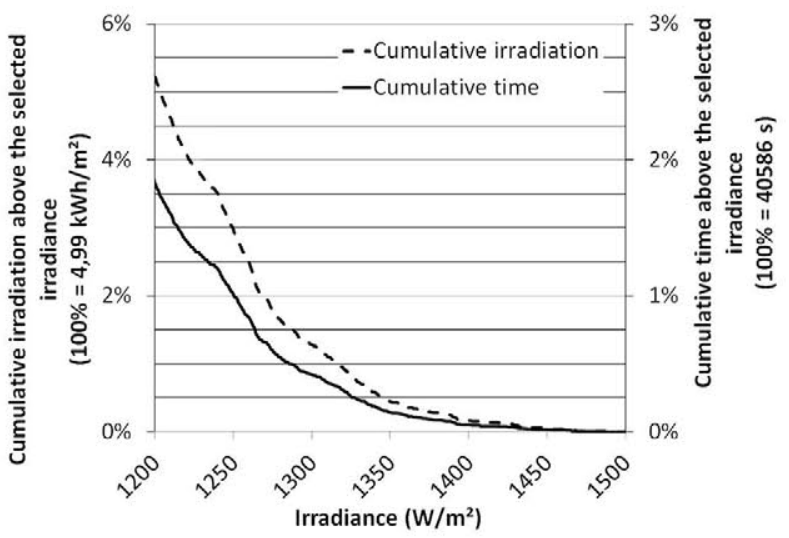

(b)

Fig. 5. Cumulative irradiation and permanence (a) from 0 to $1600 \mathrm{~W} / \mathrm{m}^{2}$ and (b) detail from 1200 up to $1500 \mathrm{~W} / \mathrm{m}^{2}$.

Table 2

Duration and quantity of continuous extreme enhancement events with readings above the extraterrestrial irradiance.

\begin{tabular}{ll}
\hline Duration (s) & Number of events \\
\hline 1 & 5 \\
2 & 2 \\
3 & 1 \\
4 & 1 \\
5 & 3 \\
7 & 1 \\
8 & 1 \\
16 & 1 \\
\hline
\end{tabular}

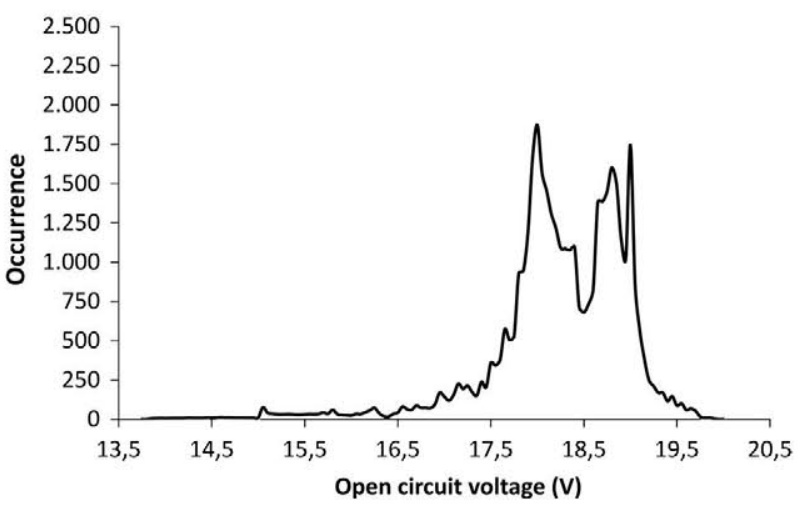

Fig. 6. Frequency distribution of observed open circuit voltage. All values remain below Voc $\operatorname{Soc}_{\mathrm{STC}}(20.8 \mathrm{~V})$.

Standard Test Condition current value associated to $1000 \mathrm{~W} / \mathrm{m}^{2}$. On the other hand, because open circuit voltage is mainly related to cell temperature and slightly related to irradiance, overvoltage phenomena are not expected. In fact, Fig. 6, which presents the frequency distribution of observed open circuit voltage, does not show values above $\operatorname{Voc}_{\text {STC }}(20,8 \mathrm{~V})$.

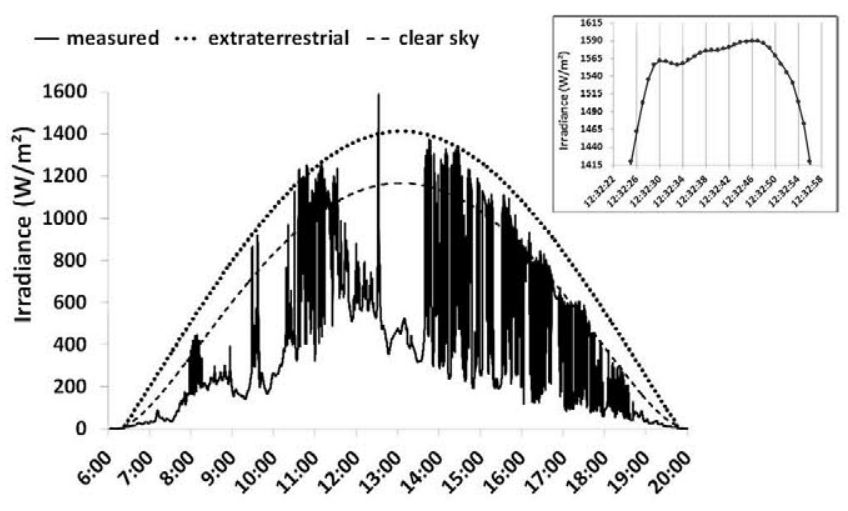

Fig. 7. Global horizontal irradiance on December 21st, when an extreme enhancement event lasted for $32 \mathrm{~s}$, with a maximum of $1590 \mathrm{~W} / \mathrm{m}^{2}$ (detail on the top-right).

\section{Results for December 21st}

On December 21st, an irradiance of $1590 \mathrm{~W} / \mathrm{m}^{2}$ was registered, being the highest value reported for Brazil and for altitudes below $1000 \mathrm{~m}$ a.s.1 so far. This extreme enhancement event is presented in Fig. 7.

As the estimated clear-sky irradiance, again computed according to Rigollier et al. (2000), for that moment is $1180 \mathrm{~W} / \mathrm{m}^{2}$, the corresponding enhancement factor is 1347. Fig. 8 shows the frequency distribution of irradiance, and Fig. $8 \mathrm{~b}$ shows the values above $1000 \mathrm{~W} / \mathrm{m}^{2}$, which comprise $11 \%$ of all readings.

Fig. 9 gives some details on the amount of irradiation contained in a particular range of irradiance and the percentage of time the readings remained in this range. From the daily measured irradiation of $5.32 \mathrm{~kW} \mathrm{~h} / \mathrm{m}^{2}, 27.4 \%$ correspond to irradiances above $1000 \mathrm{~W} / \mathrm{m}^{2}$.

The readings higher than the extraterrestrial irradiance can be grouped into 11 continuous events, whose durations and quantities are presented in Table 3. 


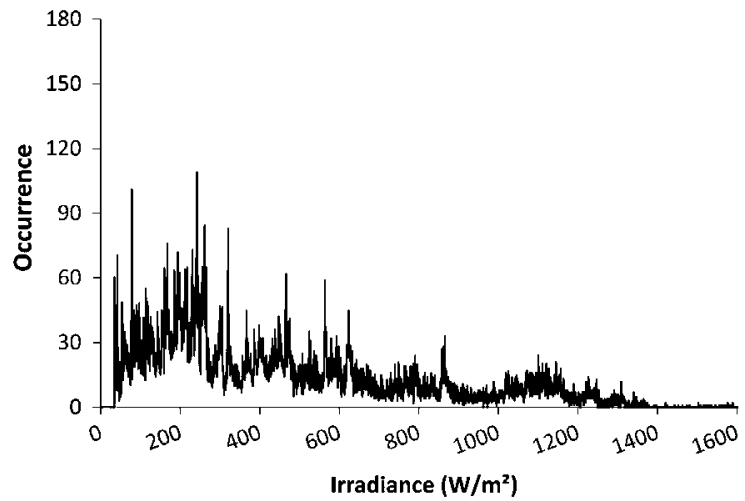

(a)

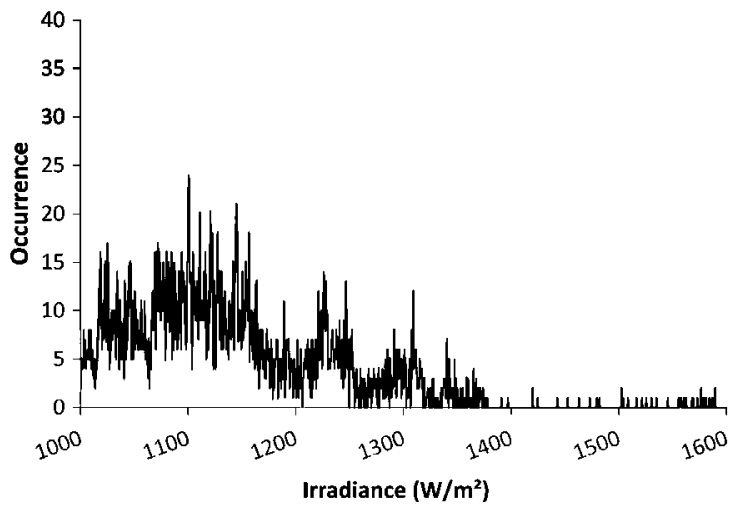

(b)

Fig. 8. Frequency distribution of irradiance (a) from 0 to $1600 \mathrm{~W} / \mathrm{m}^{2}$ and (b) detail from 1000 up to $1600 \mathrm{~W} / \mathrm{m}^{2}$.

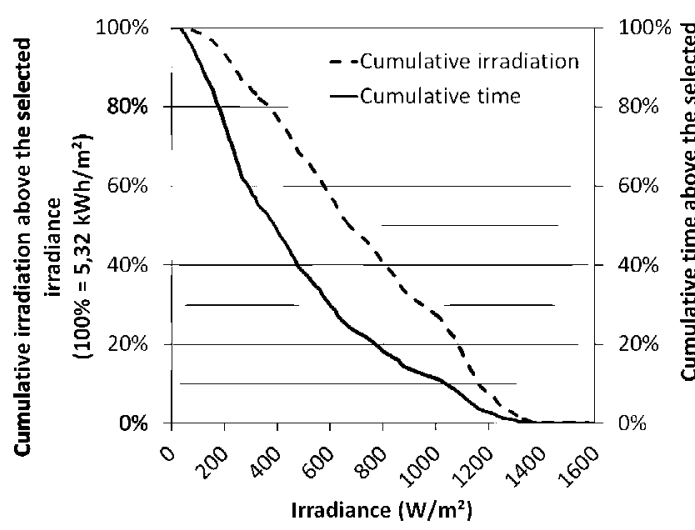

(a)

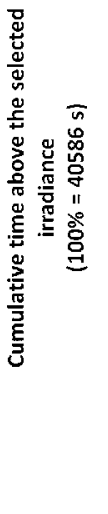

Fig. 9. Cumulative irradiation and permanence (a) from 0 to $1600 \mathrm{~W} / \mathrm{m}^{2}$ and (b) detail from $1200 \mathrm{up}$ to $1600 \mathrm{~W} / \mathrm{m}^{2}$.
Table 3

Duration and quantity of continuous extreme enhancement events with readings above the extraterrestrial irradiance.

\begin{tabular}{ll}
\hline Duration (s) & Number of events \\
\hline 1 & 4 \\
5 & 1 \\
7 & 1 \\
8 & 1 \\
10 & 2 \\
32 & 1 \\
56 & 1 \\
\hline
\end{tabular}

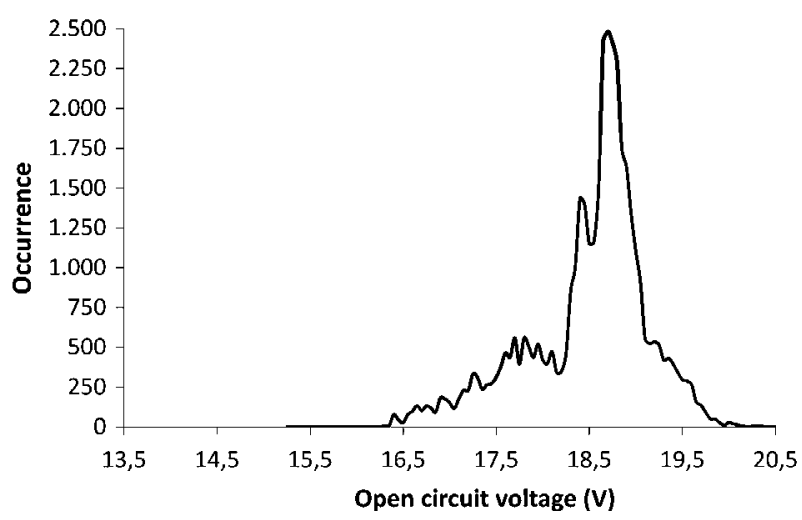

Fig. 10. Frequency distribution of open circuit voltage. All values remain below Voc STC $(20.8 \mathrm{~V})$.
Fig. 10 shows the frequency distribution of open circuit voltage, and again Voc STC $(20,8 \mathrm{~V})$ was not exceeded. It is also worth to state that the voltage did not exceed $19.45 \mathrm{~V}$ during the extreme enhancement of $1590 \mathrm{~W} / \mathrm{m}^{2}$.

\section{Conclusions}

Overirradiance caused by cloud enhancement have been observed all over the World. On November 27th, in São Paulo, Brazil, 15 continuous extreme enhancement events were registered, with a maximum of $1487 \mathrm{~W} / \mathrm{m}^{2}$. Later, on December 21st, an irradiance of $1590 \mathrm{~W} / \mathrm{m}^{2}$ was registered during an extreme enhancement event that lasted $32 \mathrm{~s}$. It corresponds to the maximum irradiance value reported for Brazil and for altitudes below $1000 \mathrm{~m}$ a.s.1. so far.

Neglecting overirradiance when sizing photovoltaic systems could lead to serious under sizing of cables, equipment and protection devices, especially overcurrent protection (the main contribution of overirradiance is in the current). It was observed, in the two analyzed days, that something around a quarter of the daily irradiation corresponds to irradiances above $1.000 \mathrm{~W} / \mathrm{m}^{2}$, value used to rate photovoltaic equipment. Even considering the 20 $25 \%$ tolerance stated at some standards, a considerable 
amount of energy would still be neglected. In fact, some authors, such as Luoma et al. (2012) and Burger and Rüther (2006), present some information regarding the importance of irradiance distribution when sizing photovoltaic equipment. This theme is not exhausted and further studies are necessary.

\section{References}

Antón, M., Gil, J.E., Cazorla, A., Fernández-Gálvez, J., Foyo-Moreno, I., Olmo, F.J., Alados-Arboledas, L., 2011. Short-term variability of experimental ultraviolet and total solar irradiance in Southwestern Spain. Atmos. Environ. 45, 4815-4821.

Burger, B., Rüther, R., 2006. Inverter sizing of grid-connected photovoltaic systems in the light of local solar resource distribution characteristics and temperature. Sol. Energy 80, $32-45$.

Emck, P., Ritcher, M., 2008. An upper threshold of enhanced global shortwave irradiance in the troposphere derived from field measurements in tropical mountains. J. Appl. Meteorol. Climatol. 47, 28282845.

Gu, L., Fuentes, J.D., Garstang, M., da Silva, J.T., Heitz, R., Sigler, J., Shugart, H.H., 2001. Cloud modulation of surface solar irradiance at a pasture site in southern Brazil. Agric. For. Meteorol. 106, 117-129.

Hansen, C.W., Stein, J.S., Ellis, A., 2010. Statistical criteria for characterizing irradiance time series. Sandia National Laboratories. Report SAND2010-7314, <http://prod.sandia.gov/techlib/access-control.cgi/ 2010/107314.pdf>.

Luoma, J., Kleissl, J., Murray, K., 2012. Optimal inverter sizing considering cloud enhancement. Sol. Energy 86, 421-429.

Piacentini, R.D., Cede, A., Barcena, H., 2003. Extreme solar total and UV irradiances due to cloud effect measured near the summer solstice at the high-altitude desert plateau Puna of Atacama (Argentina). J. Atmos. Solar Terr. Phys. 65, 727-731.

Piacentini, R.D., Salum, G.M., Fraidenraich, N., Tiba, C., 2011. Extreme total solar irradiance due to cloud enhancement at sea level of the NE Atlantic coast of Brazil. Renew. Energy 36, 409 412.

Piedehierro, A.A., Antón, M., Cazorla, A., Alados-Arboledas, L., Olmo, F.J., 2014. Evaluation of enhancement events of total solar irradiance during cloudy conditions at Granada (Southeastern Spain). Atmos. Res. 135-136, 1-7.

Rigollier, C., Bauer, O., Wald, L., 2000. On the clear sky model of the ESRA - European Solar Radiation Atlas - with respect to the Heliosat method. Sol. Energy 68, 33-48.

Suehrcke, H., McCormick, P.G., 1988. The frequency distribution of instantaneous insolation values. Sol. Energy 40, 413-422.

Tapakis, R., Charalambides, A.G., 2014. Enhanced values of global irradiance due to the presence of clouds in Eastern Mediterranean. Renew. Energy 62, 459-467.

Weigl, T., Nagl, L., Weizenbeck, J., Zehner, M., Augel, M., Öchsner, P., Giesler, B., Becker, G., Mayer, O., Betts, T., Gottschalg, R., 2012. Modelling and validation of spatial irradiance characteristics for localized irradiance fluctuations and enhancements. In: Proc. of the 27th European Photovoltaic Solar Energy Conference and Exhibition, EU PVSEC Proceedings, 2012 Sep 24-28; Frankfurt, Germany, pp. 3801-3804.

Yordanov, G.H., Midtgård, O.-M., Saetre, T.O., Nielsen, H.K., Norum, L.E., 2013a. Overirradiance (cloud enhancement) events at high latitudes. IEEE J. Photovolt. 3 (1), 271-277.

Yordanov, G.H., Saetre, T.O., Midtgård, O.-M., 2013b. 100-Miliseconds resolution for accurate overirradiance measurements. IEEE J. Photovolt. 3 (4), 1354-1360. 